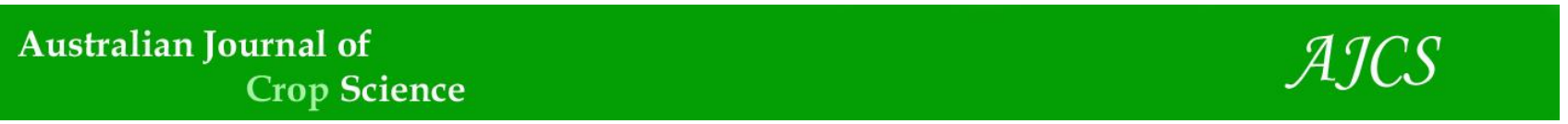

AJCS 14(10):1568-1574 (2020)

ISSN:1835-2707

doi: 10.21475/ajcs.20.14.10.p2316

\title{
Distribution of corn plants in a pneumatic system with different vacuum pressure adjustments and seed sieves
}

\author{
José Carlos Cazarotto Madaloz ${ }^{1}$, Alcir José Modolo ${ }^{1 *}$, Juan Paulo Xavier de Freitas ${ }^{1}$, José Ricardo da Rocha \\ Campos ${ }^{1}$, Murilo Mesquita Baesso ${ }^{2}$, Lucas Dotto ${ }^{1}$, Emerson Trogello ${ }^{3}$
}

\author{
${ }^{1}$ Federal Technological University of Paraná, Pato Branco, Paraná, Brazil \\ ${ }^{2}$ University of São Paulo, Pirassununga, São Paulo, Brazil \\ ${ }^{3}$ Goiano Federal Institute, Morrinhos, Goiás, Brazil
}

\section{*Corresponding author: alcir@utfpr.edu.br}

\section{Abstract}

The use of seeders with pneumatic distribution systems is increasingly demanding for plantation of corn crop. Knowledge about the operation and adjustments of the components of agricultural machines is fundamental to increase the good distribution of plants and to ensure higher productivity. The main goal of this research was to evaluate the influence of the size of the corn seed sieve under different vacuum pressure regulations on a pneumatic distribution system, to understand the longitudinal uniformity of the plants, as well as the final and individual productivity per plant. The vSet ${ }^{\circledR}$ (Precision Planting ${ }^{\circledR}$ ) pneumatic distribution system equipped with 4 corn seed sieves $(C 1, C 4, R 1$, and R4) subjected to 4 different vacuum pressure adjustments $(7,12,17$ and 22 in $\mathrm{H}_{2} \mathrm{O}^{-1}$ ) was applied as treatments on corn hybrid 30F53VYH. The design used was that of randomized blocks, with subdivided plots and 4 replications. The main plot presented the vacuum pressures and the subplots presented the sieves, each composed of two sowing lines of $20 \mathrm{~m}$ in length. The results showed that low vacuum pressure resulted in increased unevenness between corn spacings and consequently lower yield. Smaller sieves showed less gaps and higher percentages of normal spacing. The larger sieves showed higher standard deviation and more gaps. Regular and uneven gaps provided a higher number of grains per row, higher number of grains per corn spike and a higher grain yield per corn spike.

Keywords: corn; sowers; distribution; vacuum; yield; sieve.

\section{Introduction}

Corn (Zea mays L.) is a very rich food source, especially due to the large energy reserve of its grains, being used to feed animals, humans and also as a source of raw material for the industry. The national production of corn is concentrated in the South, Midwest and Southeast regions, with the states of Paraná, Mato Grosso, Rio Grande do Sul and Minas Gerais being responsible for $51.04 \%$ of the Brazilian production (Alves et al., 2015).

Corn has an incredible capacity for geographical adaptation and high productive potential per area. In productivity competition tests, it easily surpasses $15,000 \mathrm{~kg} \mathrm{ha}^{-1}$. According to Merotto Junior et al. (1999), productivity improvements in corn crops in southern Brazil were achieved through the increase in plant population per area, modern hybrids with the shorter cycle, rapid initial growth and proper plant architecture.

The adequate population and the longitudinal distribution of the plants in the sowing line play a fundamental role when high yields are pursued. Irregularity in longitudinal distribution can reduce the efficiency of water, light and nutrient usage, increasing the number of plants with delayed phenological development, fragile stems, which are dominated in the crop, producing small corn spikes (Sangoi et al., 2012).
The quality of the longitudinal distribution of seeds can be influenced by several factors such as correct regulation of the seed drill, correct choice of dosing discs and vacuum pressure, use of lubricants (graphite) and sowing operation speed. In the present study, the effect of increasing plant spacing on plant growth velocity and yield of corn crop were increased, as the speed of sowing reduced the percentage of normal seed spacing (Mantovani et al., 2015; Melo et al., 2013; Dias et al., 2009; Trogello et al., 2013).

In Brazil, most of the seed cultivators for corn cultivation are equipped with a mechanical honeycomb distribution system. However, in recent years, the seed drills are being replaced by modern models, already equipped with pneumatic distribution systems. Field estimates indicate that 20 to $25 \%$ of seed drills are equipped with a pneumatic dosing system and that $50 \%$ of the new seeders purchased are already equipped with this distribution system.

This system is being widely used in the United States, but the model of cultivation system, soil cover management and configuration of sowing are different from those adopted in Brazil. Also, information and studies on pneumatic distribution systems for corn crop in Brazilian conditions are scarce.

Every seed dosing system model requires specific 
adjustments. This is due to the particularities of the system, and to the size and shape of the seeds used. Smaller seeds need more attention so that a sowing rate above the desired does not happen. On the other hand, larger seeds typically require greater pressure force to remain attached to the dosing disc.

Thus, the main goal of this research's was to evaluate the influence of the size of the corn seed sieve under different vacuum pressure regulations on a pneumatic distribution system, focusing on longitudinal uniformity of the plants, as well as the final and individual productivity per plant.

\section{Results and discussion}

\section{Plant distribution}

The coefficient of variation (CV) of the plant distribution was not significant for the vacuum pressure levels and for the sieves studied, with an average value of $42.4 \%$. According to Vieira et al. (2006), the critical CV level should be lower than $20 \%$ to not affect the corn productivity. This level, much well below the one obtained in this experiment. Silva et al. (2015) observed a loss of $282 \mathrm{~kg} \mathrm{ha}^{-1}$ in corn productivity for each $10 \%$ increase in CV. Sangoi et al. (2012) evaluated the effects of variability in the spatial distribution of corn plants in experiments performed in two harvests, reporting losses of 64 to $83 \mathrm{~kg} \mathrm{ha}^{-1}$, per $10 \%$ of the increase in CV.

The decrease in vacuum pressure to 7 inches of $\mathrm{H}_{2} \mathrm{O}^{-1}$ resulted in an increase in the standard deviation (SD) (Figure $1 \mathrm{~A})$, indicating a greater dispersion of the data concerning the mean of the desired spacing, in which the distance between plants was higher than the ideal distance. This increase in SD at low pressure may have occurred due to the higher need for high pressure in sieves with the higher weight of a one thousand seed (WTS) to remain adhered to the dosing disc.

Lauer and Rankin (2004) observed a reduction of $1.06 \%$ in corn productivity with each $1 \mathrm{~cm}$ of increase in SD (above 12 $\mathrm{cm}$ of SD). Therefore, we can consider that the three higher vacuum pressures $\left(12,17\right.$ and 22 in $\left.\mathrm{H}_{2} \mathrm{O}^{-1}\right)$ maintained levels of SD within acceptable limits.

Regarding the sieves, the smaller sizes (C4 and R4) presented a lower standard deviation, when compared to larger sieves (C1 and R1) (Table 1). However, the significant difference was only occurred between the C4 and R1 sieves, which were the sieves with the highest WTS difference and seed size, according to the seed analysis (Table 3).

The percentage of gap spacing was increased with the reduction of vacuum pressure (Figure 1B). This result follows the expected trend, since the seeding work performed with pneumatic seeder at a low vacuum pressure in the system results in poor retention of the seed in the orifice of the dosing disk, thus falling or non-retention. It is believed that this result is related to the low retention force of the seed in the orifice of the dosing disc; thus, being easily removed by the eliminator "fingers" (singulator), resulting in faulted spaces. These results corroborate the work of Singh et al. (2005), where low failure rates have been observed with the use of higher vacuum pressure and low planting velocities. Small sized sieve seeds and smaller WTS, such as the C4 sieve, are easily retained in the dosing disc orifices and require a greater action of the eraser "fingers" to be removed. Therefore, they present a lower percentage of faulty spacing (Table 1). Therefore, sieves with larger size and WTS (R1) require greater suction force to remain retained in the orifices of the dosing disc as they pass through the eliminating "fingers." Thus, they present the highest percentages of failed spacing.

According to Rascon et al. (2012), the eSet (Precicion Planting ${ }^{\circ}$ set requires higher vacuum pressure than the ProMax40 (John Deere) in order to maintain distribution uniformity. However, the shape of the seed must be taken into the account to adjust the system pressure.

The double spacing between plants has not been significantly influenced by the different vacuum pressures, presenting an average value of $3.56 \%$. Plants arranged very close to each other, called double, can result in low or no production. This is due to intraspecific competition for nutrients, water, and light competition, acting as if it were an invasive plant. In this sense, one must always seek a better spatial occupation along the line by the plants, minimizing intraspecific competition between them (Silva et al., 2015), since double or triple space with separate plants from 0 to $3 \mathrm{~cm}$, cause a reduction from 6 to $10 \%$ productivity when compared to plants with uniform spatial distribution (Liu et al., 2004).

As for the sieves, C4 presented the highest percentage of double spacings (Table 1), which is the allocation of two or more seeds occurred in the same place. We can attribute this to the fact that this sieve is smaller in size and WTS. A flat shape can make the dosing system easily retain more than one seed in the same hole in the dosing disk. In turn, the double elimination system, consisting of five eliminating "fingers" (singulators), did not present enough capacity to remove the exceeding seeds of the orifice.

The normal spacing between plants has not been significantly influenced by the different vacuum pressures, presenting an average value of $84.60 \%$. The $\mathrm{C} 4$ and $\mathrm{R} 1$ sieves presented statistical differences between them for the normal spacing (EN). The sieve R1 has the lowest percentage of EN (81.80\%), presenting a high percentage of irregular spacings (EF and/or ED). This sieve presented the highest percentages of EF. This is due to the greater need for pressure to ensure the retention of the seed in the orifice of the dosing disc until its release in the conducting tube. On the other hand, the $\mathrm{C} 4$ sieve presented higher values of EN $(87.63 \%)$. This is due to the greater ease of retention in the dosing disc because it presents smaller dimensions and WTS. The increase in spatial non-uniformity of corn seeds along with the planting line causes a reduction in several corn yield components, such as stem diameter, spike length, number of rows per spike, number of grains per row, the weight of one hundred grains and yield of grains (Silva et al., 2015). According to Sangoi et al. (2012) the increase of the irregularity of the plants' spatial distribution in the row results in a decrease in grain yield, due to the lower production of grains per square meter.

The reduction in vacuum pressure resulted in an increased mean distribution uniformity (Figure $1 \mathrm{C}$ ), which is the mean distance between plants. The index of failed spacings can justify this, since the mean distribution uniformity has been measured using the average of all spacings directly influencing this index. This in turn was higher for these two sieves.

The $\mathrm{C} 1$ and R1 sieves have greater sizes and greater WTS than the $\mathrm{C} 4$ and R4 sieves, thus requiring higher vacuum pressure in the dosing systems to retain the seeds in the holes and avoid planting failures. The greater the mean 
Table 1. Mean standard deviation (SD) values, faulty spacing (EF), normal spacing (EN), Double spacing (ED) sowing depth (PS), initial population (PI) and dominated corn plants due to different screens.

\begin{tabular}{lllll}
\hline Screens & SD & EF (\%) & ED (\%) & EN (\%) \\
\hline C1 & $13.69 \mathrm{ab}$ & $11.90 \mathrm{ab}$ & $3.00 \mathrm{~b}$ & $85.09 \mathrm{ab}$ \\
C4 & $11.07 \mathrm{~b}$ & $7.92 \mathrm{~b}$ & $4.45 \mathrm{a}$ & $87.63 \mathrm{a}$ \\
R1 & $15.13 \mathrm{a}$ & $14.75 \mathrm{a}$ & $3.46 \mathrm{ab}$ & $81.80 \mathrm{~b}$ \\
R4 & $12.75 \mathrm{ab}$ & $12.78 \mathrm{a}$ & $3.34 \mathrm{ab}$ & $83.89 \mathrm{ab}$ \\
\hline
\end{tabular}

*Means followed by the same letter do not statistically differ to a $5 \%$ probability of error by Tukey's test.
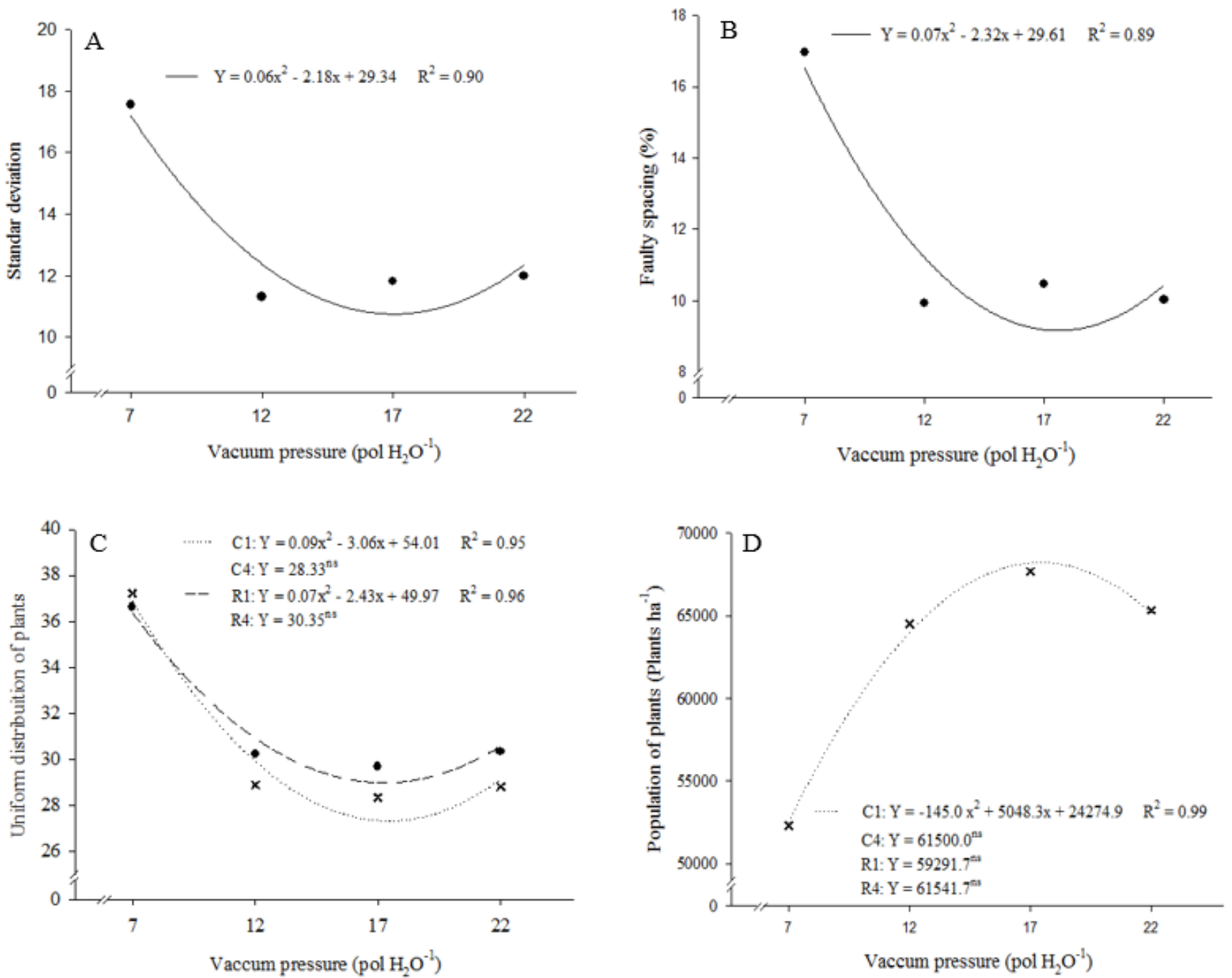

Fig 1. Standard deviation (A), faulty spacing (B) as a function of different vacuum pressures, uniform distribution of plants (C) and final population of corn plants (D) have interaction with sieves with vacuum pressure.

Table 2. Mean number of rows per spike, number of grains per row, number of grains per spike and yield of grains per spike of corn as a function of plant profile.

\begin{tabular}{|c|c|c|c|c|}
\hline Plant profile & $\begin{array}{c}\text { № of rows per } \\
\text { spike }\end{array}$ & $\begin{array}{c}\text { № of grains per } \\
\text { row }\end{array}$ & $\begin{array}{c}\text { № of grains per } \\
\text { spike }\end{array}$ & $\begin{array}{c}\text { yield of grains per } \\
\text { spike }(\mathrm{g})\end{array}$ \\
\hline Normal spacing & 15.8 a & $37.7 \mathrm{a}$ & 595.5 a & 229.5 a \\
\hline Faulty spacing & $15.7 \mathrm{a}$ & 39.0 a & $613.0 \mathrm{a}$ & $236.3 \mathrm{a}$ \\
\hline Double spacing & $15.8 \mathrm{a}$ & $33.3 b$ & $527.3 \mathrm{~b}$ & $203.1 \mathrm{~b}$ \\
\hline Dominated plants & $15.4 \mathrm{a}$ & $22.3 \mathrm{c}$ & $345.4 \mathrm{c}$ & $133.1 \mathrm{c}$ \\
\hline
\end{tabular}




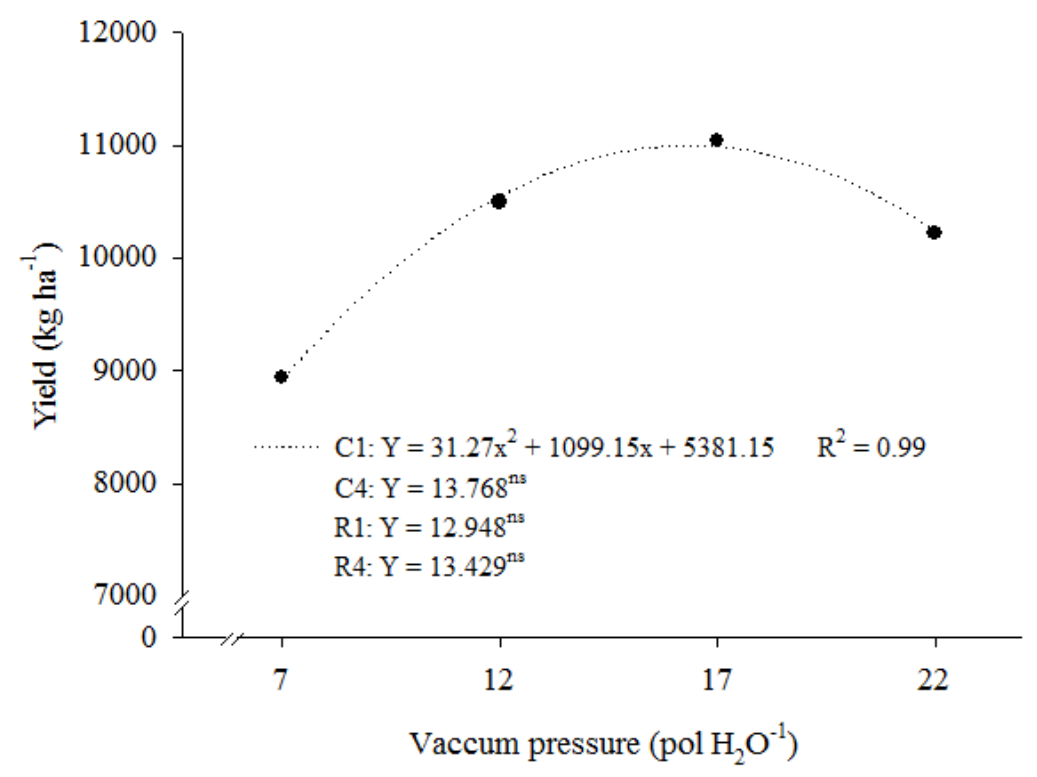

Fig 2. Mean values of corn grain yield as a function of different vacuum pressures.

Table 3. Description of the seeds used in the experiment for the sieve, germination (Ger), purity (Pur), length (Leng), width (Wid), thickness (Thic), weight of one thousand seeds (WTS) and Sphericity (Sph).

\begin{tabular}{llllllll}
\hline Screens & Ger* & Pur* & $\begin{array}{l}\text { Leng } \\
(\mathrm{mm})^{* * *}\end{array}$ & $\begin{array}{l}\text { Wid } \\
(\mathrm{mm})^{* *}\end{array}$ & $\begin{array}{l}\text { Thic } \\
(\mathrm{mm})^{* *}\end{array}$ & $\begin{array}{l}\text { TGM } \\
(\mathrm{g})^{* *}\end{array}$ & Sph $(\varnothing)^{* * *}$ \\
\hline C1 & $99 \%$ & $100 \%$ & 10.45 & 8.84 & 4.80 & 333.8 & $73.3 \%$ \\
C4 & $99 \%$ & $100 \%$ & 10.61 & 6.75 & 4.46 & 236.3 & $64.4 \%$ \\
R1 & $99 \%$ & $100 \%$ & 9.75 & 8.83 & 6.01 & 371.6 & $82.6 \%$ \\
R4 & $99 \%$ & $100 \%$ & 10.08 & 6.61 & 5.38 & 246.8 & $70.8 \%$ \\
\hline
\end{tabular}

*Reports of germination and purity performed by Du Pont do Brasil SA - Pioneer Seeds Division (RENASEM No: GO-01198/2011); **Evaluations of length, width, thickness, and WTS performed according to MAPA standards (2009); ***Sphericity ( $\varnothing$ ) according to Karayel et al., 2004.

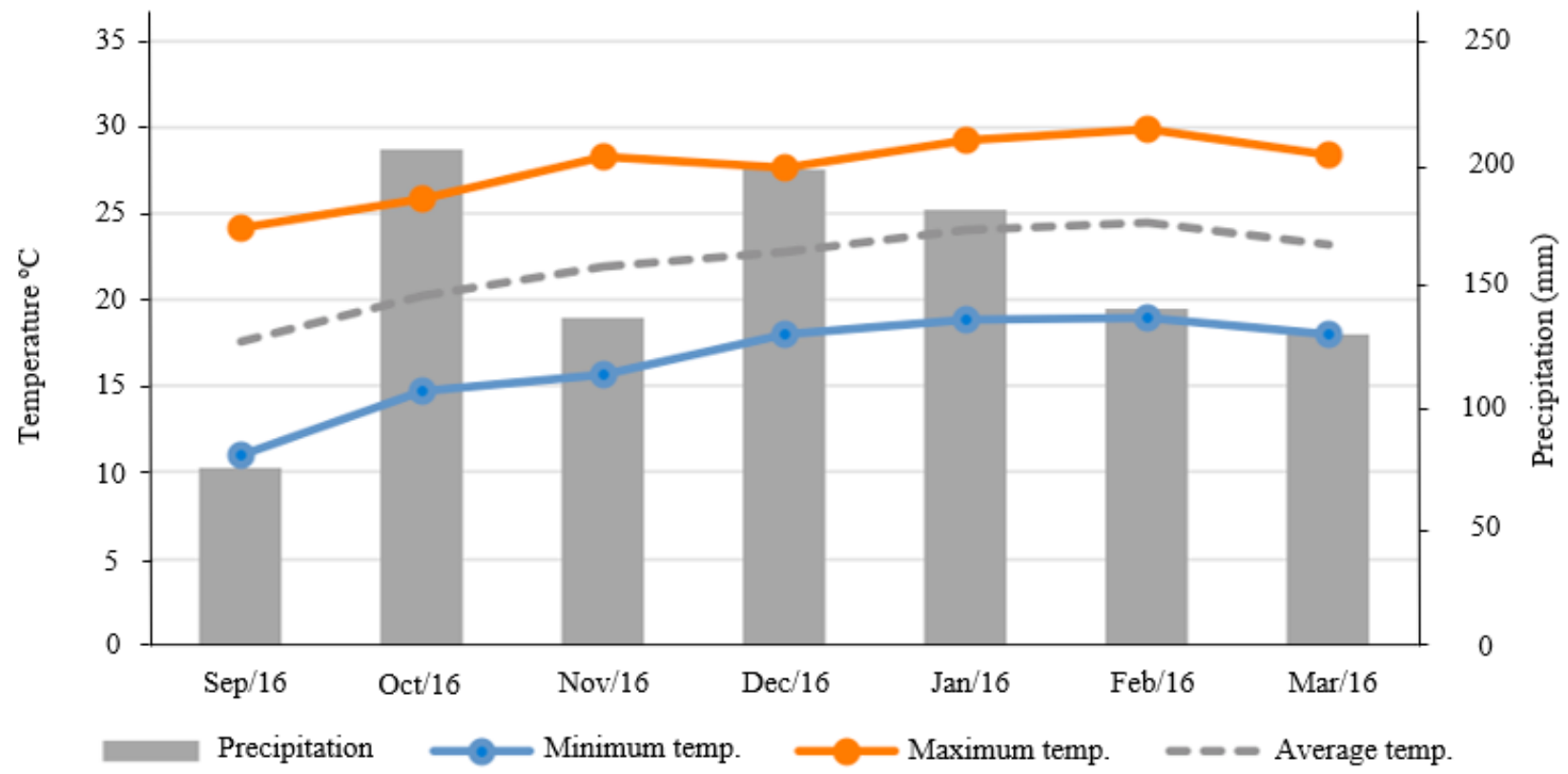

Fig 3. Climatic condition during the $2016 / 2017$ agricultural crop for the city of Verê/PR. 
distance between plants, the highest is the heterogeneity (a measure of regularity) of the distance between plants. In turn, the greater the measure of regularity, the productivity may be significantly lower (Storck et al., 2015).

According to Yasgi and Degirmencioglu (2007), working with modeling for pneumatic distribution systems, the mean diameter, geometry, and mass of the seeds determine the level of vacuum. Results of Karayel et al. (2004), show that the vacuum seeder efficiency of uniformity of distribution differs in lower or higher vacuum pressures and high seeding speeds.

\section{Crop yield parameters}

For the final population of plants, there was significant interaction between the factors. However, only the $\mathrm{C} 1$ sieve presented significant statistical model (Figure 1D). The C1 sieve had a larger size and greater WTS than the other sieves, which requires a higher vacuum pressure for its retention in the dosing disc. This way, the lower pressure results in higher rates of planting failure, and in turn, lower plant populations. Unlike this work, Vasquez et al. (2015) did not observe any influence on the final population, studying different sieves and corn seed forms, whereas they reached a final average population of 58,765 plants $\mathrm{ha}^{-1}$.

The percentage of dominated plants was not influenced by vacuum pressures as well as different sieves, with a mean value of $8.25 \%$. The irregularity in the spatial distribution lines may reduce water use efficiency, light and community nutrients, increasing the number of plants with delayed phenological development, fragile stalks which get dominated in the crop, producing small spikes (Sangoi et al., 2012).

Except for the number of rows per spike, all other evaluated parameters presented significant differences (Table 2). The number of rows per spike is a variable genetic character among hybrids, meaning each hybrid can produce a certain number of rows of grains. Trogello et al. (2013) evaluated 14 different commercial sieves in corn yield components and did not observe any influence on different sizes of sieves on the number of rows per spike.

The number of grains per row, grain production per spike and, consequently, grain yield per spike was impaired when there was a double horizontal distribution, or the plant showed a slow initial development, resulting in a dominated plant. The proximity between plants (double) or delayed development may affect plant resources uptake and thus affect the formation of grains in the row.

According to Sangoi et al. (2010), the adequacy of the plant arrangement directly affects the interception of incident solar radiation, which is one of the main factors of productivity definition. Often, we can observe that there has been division, formation, and fertilization of the egg in the row. However, plant ends up aborting the grains in tip of the spike due to lack of resources.

The spikes formed within double-spaced plants and dominated plants had a reduction in the number of grains per spike of 11.5 and $42.0 \%$, respectively, when compared to spikes of normal spacing plants. The spikes in failed spacings showed an increase in the number of grains per spike of $3 \%$, compared to the spikes of normal spacings. Thus, the plants neighboring a planting failure will be able to compensate in only $6 \%$ of the productivity, because the corn plants were not able to compensate the planting failures.

The grain yield showed a significant interaction between the factors of vacuum pressure and sieve $(p \leq 0.01)$. However, only the $\mathrm{C} 1$ sieve, showed a model that fitted to the data (Figure 2).

The corn productivity is a result of the condition of the environment provided for the plants for the expression of the productive potential, which is the maximum production of grains per plant. An optimal population of plants must be implanted in such a way that can express its productive potential. However, the competition with other plants for resources does not happen. Likewise, plant populations below the ideal result in underutilization of resources, and consequently low yields.

The plants with uniform spacing present greater efficiency in the assimilation of water, light, and nutrients, since intraspecific competition is minimal (Silva et al., (2015). In addition to the correct population of plants, the correct spatial arrangement between leads to a correct distribution of the plants in the area (Horbe et al., 2016), which is fundamental for a high yield.

In the experiment, we can observe that the larger sieves require a higher vacuum pressure to remain adhered to the dosing disc until the moment of its release. The sieve $\mathrm{C} 1$, besides having a higher WTS (333.8 g), has a smaller thickness $(4.80 \mathrm{~mm})$ than the studied round sieves (R1 and R4). This can lead to a suction loss of the seed to the disk when it is poorly positioned in the hole, resulting in planting failures. This can be confirmed at the pre-harvest stage by evaluating the final population of plants (Figure 1D), where it has been observed that the $\mathrm{C} 1$ sieve presented the lowest values of final plant population, sown at a lower pressure (7 in $\mathrm{H}_{2} \mathrm{O}^{-1}$ ).

Several studies have demonstrated the influence of seed size on crop yield components (Kara, 2011; et al., 2011, Trogello et al., 2013; De padua et al., 2010), while evaluating 14 different sizes of corn seeds. They obtained the highest means of productivities using larger seeds. Kara (2011) and Enayatgholizadeh et al. (2011) evaluated three sizes of corn seeds and obtained a maximunm productivity with the use of larger seeds.

\section{Materials and methods}

\section{Experiment location and characteristics}

The experiment was conducted in the summer crop $2016 / 2017$ in commercial farming in the municipality of Verê - PR, located at coordinates $25^{\circ} 54^{\prime} 35.50^{\prime \prime}$ south latitude and $52^{\circ} 59^{\prime} 8.08^{\prime \prime}$ west longitude, with an elevation of $620 \mathrm{~m}$, with soil classified as Red Latosol (EMBRAPA, 2013). The climatic condition of the 2016/2017 crop, during the conduction period of the experiment, can be observed in Figure 3.

In the conduction area of the experiment, the no-tillage system had been adopted for more than ten years, and in the previous crop 2015/2016 soybean and later beans were grown. During the winter period, the area remained fallow, which resulted in a low amount of straw ( $<2.0 \mathrm{t} \mathrm{MS} \mathrm{ha}^{1}$ ) in the soil at the time of the experiment.

\section{Installation and conduction of the experiment}

Twenty days before planting, the desiccation of the cover plants (black oats) in the area was carried out with glyphosate (Roundup ), at the dose of $2.5 \mathrm{~L} \mathrm{ha}^{-1}$. The early cycle of simple hybrid 30F53VYH (CRM 134) was used. Mineral fertilization was carried out with potassium 
fertilization at pre-sowing stage with distribution of $200 \mathrm{~kg}$ $\mathrm{ha}^{-1}$ of $\mathrm{KCl}(00-00-60)$, and disk distributor. At sowing, $355 \mathrm{~kg}$ $\mathrm{ha}^{-1}$ MAP fertilizer (11-52-00) was used as the base fertilizer. Nitrogen cover fertilization was performed in two different seasons (V2/3 and V5), using Super N urea (45-00-00) at a dose of $150 \mathrm{~kg} \mathrm{ha}^{-1}$, in each application.

A precision seeder-fertilizer spreader (Stara), Victoria Top 4950, with model vSet pneumatic distribution system was used, with the option of variable rate distribution of seeds and fertilizer, by means of the monitor control. Another important feature was the utilization of a system of five singular "fingers" to eliminate double seeds in the same orifice, those of permanent position and without adjustment.

The sowing velocity was $4.3 \mathrm{~km} \mathrm{~h}^{-1}$ (gait $1 \mathrm{~B}$ ), so that there was no distribution influence on the treatments. The sowing rate was adjusted for the final population of 68,000 plants ha ${ }^{-1}$, equivalent to 3.4 seeds $\mathrm{m}^{-1}$, the seeding depth was preliminarily adjusted to $6.0 \mathrm{~cm}$.

\section{Experimental design}

The experimental design consisted of a randomized block design with subdivided plots, and the treatments were composed of four negative vacuum pressure levels $(7,12,17$ and 22 inches of water column - inch of $\mathrm{H}_{2} \mathrm{O}^{-1}$ ) and the four different seed sieves ( $\mathrm{C} 1, \mathrm{C} 4$ (flat-shaped seeds), R1 and R4 (round-shaped seeds)), with four replicates, totaling 64 experimental units. Each experimental unit consisted of a useful area of 2 sowing rows of $20 \mathrm{~m}$ of length each. The description and evaluations of the seeds are shown in Table 3.

The sowing depth and initial plant population evaluations were performed after stabilization of the plant stand in V4. Seed depth measurement has been performed on 10 plants of each experimental unit, cutting the plant at the soil surface level and then measuring the distance from the cut to the position of the seed.

\section{Parameters evaluated}

\section{Plant distribution}

To evaluate plant distribution, the plant-to-plant distance was measured in the valid area of each experimental unit, using the methodology proposed by Kurachi et al. (1989), classifying the spacings into three groups: double spacing (ED): when the distance between plants is less than 0.5 of the standard distance (Dp); normal space: when they fit between $>0.5$ and $<1.5$ to $\mathrm{Dp}$; failed space $(\mathrm{EF})$ : when the distance between plants is greater than 1.5 to $D p$, where $D p$ is the recommended standard distance for the crop at a given sowing rate. In addition to these parameters, the standard deviation (SD), and coefficient of variation (CV) were calculated.

\section{Crop yield parameters}

For the initial and final population evaluations of plants (PFP), plants were counted in the two rows of $20 \mathrm{~m}$ for each experimental unit.

Dominated plants, plants neighboring sowing faults and double plants were also evaluated to measure productivity losses per plant. For measuring the losses in dominated, faulted and doubled plants, the individual evaluation of the grain yield of 50 plants at random in the test has been performed, which is 50 dominated plants, 50 double plants and 50 planting faults.

For yield estimation, the yield components was evaluated, considering the average grain yield per plant (number of rows per spike, number of grains per row, the weight of a thousand grains and the population of plants in the area). Besides, the productivity of the dominated plants and the yield related to the condition of horizontal distribution of the plants in the line were considered, which are plants in the condition of a normal distribution, failure and double.

The evaluation of the standard spikes was performed in five spikes, each in the two lines of each experimental unit, measuring the number of rows per spike and number of grains per row. For the measurement of a thousand-grain weight, 30 random spikes were collected and the total number of grains and measuring the humidity were counted using a FARMEX MT-PRO model manual for each sample, for conversion to a standard moisture of $13 \%$.

\section{Statistical analysis}

Data have been submitted to analysis of variance by the $F$ test $(p \leq 0.05)$, and when significant, the means of the sieves were compared using the Tukey test at $5 \%$ probability. For the vacuum pressure, the polynomial regression analysis was adopted. The models were selected by the criterion of greater $R^{2}$ and the significance $(p \leq 0.05)$ of the parameters of the equation. The spike evaluation data were analyzed using the Tukey test, at a $5 \%$ probability. The software $R(R$ Development Core Team, 2011) was employed to analyze the data.

\section{Conclusion}

Low vacuum pressure resulted in increased unevenness between corn spacing and consequently lower yield. Smaller sieves showed lower gaps and higher percentages of normal spacing. The larger sieves showed higher standard deviation and gaps. Regular and uneven gaps provided a higher number of grains per row, a higher number of grains per corn cob and a higher grain yield per spike. Thus, it can be concluded that the 17 inch $\mathrm{H}_{2} \mathrm{O}^{-1}$ vacuum pressure sieve $\mathrm{C} 1$ presented better results for the valid parameters.

\section{Acknowledgements}

The authors thank the Coordenação de Aperfeiçoamento de Pessoal de Nível Superior (CAPES) and Conselho Nacional de Pesquisa (CNPq) for their financial assistance.

\section{References}

Alves BM, Cargnelutti Filho A, Burin C, Toebe M, Silva LP (2015) Divergência genética de milho transgênico em relação à produtividade de grãos e da qualidade nutricional. Cie Rural. 45:884-891.

CONAB - Companhia Nacional de Abastecimento (2018). Acompanhamento da safra brasileira de grãos - 5은 Levantamento de Safra 2017/18, v. 5, fevereiro 2018. Available in: http://www.conab.gov.br/OlalaCMS/uploads/arquivos/18 _02_08_17_09_36_fevereiro_2018.pdf. Accessed in: 18 feb. 2018.

Dias VO, Alonço AS, Baumhardt UB, Bonotto GJ (2009) 
Distribuição de sementes de milho e soja em função da velocidade e densidade de semeadura. Cie Rural. 39: 17211728.

Enayatgholizadeh MR, Alami Saeid KH, Bakhshandeh AM, Dehghan Shoar M, Ghaineh MH, Sharafizadeh M (2011) Response of the morphologic characteristics of S.C704 maize affected by the source and seed size in Khuzestan. Aust J Basic and Appl Sci. 5: 369-374.

Hörbe TAN, Amado TJC, Reimche GB, Schwalbert RA, Santi A L, Nienow C (2016) Optimization of Within-Row Plant Spacing Increases Nutritional Status and Corn Yield: A Comparative Study. Agr J. 108: 1962-1971.

Kara B (2011) Effect of seed size and shape on grain yield and some ear characteristics of maize. Res Crops. 12: 680685.

Karayel D (2009) Performance of a modified precision vacuum seeder for no-till sowing of maize and soybean. Soil Till Res. 104: 121-125.

Karayel D, Barut ZB, Özmerzi A (2004) Mathematical modelling of vacuum pressure on a precision seeder. Bio Eng. 87: 437-444.

Kurachi SAH, Costa JAS, Bernardi JA, Coelho JLD, Silveira GM (1989) Avaliação tecnológica de semeadoras e/ou adubadoras: tratamento de dados de ensaios e regularidade de distribuição longitudinal de sementes. Bragantia. 48: 249-262.

Lauer JG, Rankin M (2004) Corn response to within row plant spacing variation. Agr J. 96: 1464-1468.

Liu W, Tollenaar M, Stewart G, Deen W (2004) Impact of planter type, planting speed, and tillage on stand uniformity and yield of corn. Agr J. 96: 1668-1672.

Mahl D, Furlani CEA, Gamero CA (2008) Efficiency of pneumatic and horizontal perforated disk meter mechanism in corn no-tillage seeders in soil with different mobilization reports. Eng Agrícola. 28: 535-542.

Mantovani EC, Cruz JC, Oliveira AC (2015) Avaliação em campo de uma semeadora-adubadora para semeadura de milho de alta densidade. Rev Bra de Milho e Sorgo. 14: 3848.

Melo RP, Albieiro D, Monteiro LA, Souza FH, Silva JG (2013) Qualidade na distribuição de sementes de milho em semeadoras em um solo cearense. Rev Cie Agro. 44: 94101.

Modolo AJ, Carnieletto R, Kolling EM, Trogello E, Sgarbossa M (2010) Desempenho de híbridos de milho na Região Sudoeste do Paraná sob diferentes espaçamentos entre linhas. Rev Cie Agro. 41: 435-441.

Özmerzi A, Karayel D, Topacki M (2002) Effect of Sowing Depth on Precision Seeder Uniformity. Bio Eng. 82: 227230.

R Development Core Team (2014) R: A language and environment for statistical computing. R Foundation for Statistical Computing, Vienna, Austria.

Rascon J, Porter WM, Taylor R (2012) Evaluation of Corn Seed Vacuum Metering Systems. In: ASABE Annual International Meeting. Anais. ASABE, Dallas, Texas.
Sangoi L, Almeida ML, Horn D, Bianchet $P$, Gracietti A, Schmitt A, Schweitezer C (2004) Tamanho de semente, profundidade de semeadura e crescimento inicial do milho em duas épocas de semeadura. Rev Bra de Milho e Sorgo. 3: 370-380.

Sangoi L, Schmitt A, Vieira H, Picoli JRGJ, Souza CA, Casa RT, Schenatto DE, Giordani W, Boniatti CM, Machado GC, Horn D (2012) Variabilidade na distribuição espacial de plantas na linha e rendimento de grãos de milho. Rev Bra de Milho e Sorgo. 11: 268-277.

Sangoi L, Schweitzer C, Silva PRF, Schmitt A, Vargas VP, Casa RT, Souza CA (2011) Perfilhamento, área foliar e produtividade do milho sob diferentes arranjos espaciais. Pesq Agro Bra. 46: 609-616.

Silva FH, Cunha PCR, Almeida ACS, Araujo LS, Jakelaitis A, Silveira PM (2015) Production components of corn as function of seed distribution along the planting row. Rev Bra Eng Agrí Amb. 19: 1172-1177.

Silva FH, Cunha PCR, Almeida ACS, Araújo LS, Jakelaitis A, Silveira PM (2015) Production components of corn as function of seed distribution along the planting row. Rev Bra de Eng Agrícola e Ambiental. 19: 1172-1177.

Singh RC, Singh G, Saraswat DC (2005) Optimisation of Design and Operational Parameters of a Pneumatic Seed Metering Device for Planting Cottonseeds. Bio Eng. 92: 429-438.

Stork L, Modolo AJ, Brum B, Trogello E, Franchin MF, Adami PF (2015) Medida de regularidade do espaçamento de plantas de milho em diferentes sistemas de manejo. Rev Bra Eng Agrícola Ambiental. 19: 39-44.

Soil Survey Staff (2014) Keys to soil taxonomy. Department of Agriculture. Natural Resources Conservation Service. 12 ed. $372 p$.

Trogello E, Modolo AJ, Scarsi, M, Dallacort R (2013) Manejos de cobertura, mecanismos sulcadores e velocidades de operação sobre a semeadura direta da cultura do milho. Bragantia. 72: 101-109.

Vazquez GH, Arf O, Sargi BA, Pessoa ACO (2012) Influência do tamanho e forma da semente de milho sobre o desenvolvimento da planta e a produtividade de grãos. Biosci J. 28: 16-24.

Vieira Junior PA, Molin JP, Dourado Neto D, Manfron PA, Mascarin LS, Faulin GDC, Detomini ER (2006) População de plantas e alguns atributos do solo relacionados ao rendimento de grãos de milho. Acta Sci Agron. 28: 483492.

Weirich Neto PH, Justino A, Namur RT, Domingues J, Garcia LC (2012) Comparison of metering mechanisms of corn seed. Eng Agrícola. 32: 981-988.

Weirich Neto PH, Fornari A, Justino A, Garcia L (2015) Qualidade na semeadura do milho. Eng Agrícola. 35: 171179.

Yasgi A, Degirmencioglu A (2007) Optimization of the seed spacing uniformity performance of a vacuum-type precision seeder using response surface methodology, Bios Eng. 97: 347-356. 